\title{
ПІДГОТОВКА НАВЧАЛЬНО-МЕТОДИЧНОЇ ДОКУМЕНТАЦІЇ ДО ПРАКТИЧНИХ ЗАНЯТЬ ТА ВПЛИВ ЇЇ ЗАСТОСУВАННЯ НА ЯКІСТЬ ЗНАНЬ СТУДЕНТІВ
}

\author{
О. В. Попова
}

Дніпродзержинське медичне училище

У статті проаналізовано основні етапи проведення практичних занять в медичних навчальних закладах I рівня акредитації та їх методичне забезпечення. Якість знань студентів залежить від різноманітних методів навчання і контролю.

\section{WAYS OF FORMATION AND IMPROVEMENT OF EDUCATIONAL AND METHODICAL COMPLEX IN THE TRAINING OF JUNIOR MEDICAL}

\author{
O. V. Popova
}

\section{Dniprodzerzhynsk Medical College}

The article says about the main stages of practical training in medical institution accreditation Level 1 and methodological documentation. The quality of students knowledge is dependent on a variety of teaching methods and control.

Вступ. Специфіка підготовки студентіву медичному училищі зумовлена цілями й особливостями їхньої майбутньої професійної діяльності. Відповідно до галузевих освітніх стандартів молодший медичний працівник повинен виконувати важливі професійносоціальні функції: на основі глибоких знань за даними об'єктивного та лабораторного дослідження вміти оцінити стан пацієнта, визначити прогноз, досконало володіти технікою медичних маніпуляцій, самостійно і швидко ухвалити рішення, особливо при невідкладних станах, мати розвинуте клінічне мислення, стояти на активних життєвих позиціях, проводити санітарноосвітню роботу серед населення.

Це може успішно реалізуватись лише за умови, коли в основі підготовки фахівців є логіка розвитку і удосконалення системи професійної діяльності викладачів через призму якісної підготовки навчальнометодичної документації до заняття [1].

Основна частина. Підготовка і проведення практичних занять з основ медсестринства вимагає від викладача певної системи професійних психологопедагогічних, методичних знань, навичок і вмінь, що відповідають сучасним вимогам педагогічної діяльності. Викладач має вміти правильно визначати на-

(C) О. В. Попова, 2016 вчальні цілі та їх диференціювати, вміти структурувати зміст матеріалу, підбирати адекватну систему методів контролю та навчання, складати тестові завдання різного рівня складності, складати навчальні задачі та інструктивні методичні матеріали для організації самостійної роботи студентів, реалізовувати міждисциплінарну інтеграцію, розробляти сценарії для ігрових методів навчання тощо [2, 3].

Навчальні цілі (цілі діяльності) визначають, які саме дії повинен виконувати студент і що саме контролюється під час оцінювання досягнення поставленої ним мети [4].

Визначаючи навчальні цілі, необхідно додержуватись основних правил.

Правило 1. Правильно вибирати дієслово для опису професійної поведінки.

Правило 2. Вказувати на умови, за яких студент демонструватиме здатність виконати завдання, а також визначати критерії або стандарти, згідно з якими здійснюватиметься оцінювання знань.

Правило 3. Цілі необхідно формулювати за допомогою однозначних термінів.

Правило 4. Формулювання цілей має бути чітким, не перевантаженим зайвими словами.

Правило 5. Цілі мають бути унітарними, тобто кожне положення повинно належати до одного процесу. 
Чіткому визначенню цілей навчання сприяє їх класифікація (таксономія). Першою було розроблено систему класифікації у пізнавальній сфері (Bloom, 1956 р.). Наступним кроком було створення системи класифікації в емоційній сфері (Krathwoll, 1964 р.) і, нарешті, Simpson (1966 р.), Kibler (1970 р.) i Harrow (1972 р.) розробили систему класифікації цілей навчання в психомоторній області. Таксономія цілей навчання являє собою опис цілей навчання у термінах професійної діяльності (поведінки).

Пізнавальна сфера містить цілі, що описують знання та інтелектуальні здібності студентів.

Класифікація пізнавальної сфери включає шість класів цілей, розміщених відповідно до складності: знання, розуміння, застосування, аналіз, синтез та оцінювання знань [5].

Знання - це здатність запам'ятовувати факти.

Розуміння - здатність розуміти матеріал, що вивчається. Студент розуміє і може самостійно, логічно відтворити зміст теоретичного матеріалу.

Застосування - здатність використовувати засвоєний матеріал у стандартних та нових ситуаціях.

Аналіз - здатність структурувати навчальний матеріал так, щоб була зрозумілою загальна організаційна структура.

Синтез - здатність поєднати окремі частини знань з метою отримання цілого, що набуває нової якості.

Оцінювання - здатність давати оцінку даному навчальному матеріалу в рамках поставленої мети.

Емоційна сфера включає цілі, що стосуються емоцій, почуттів, цінностей, позицій та пов'язані зі змінами, які відбуваються в них.

Ця сфера поділяється на п'ять основних класів: сприймання, реагування, переконаність, селективність, індивідуальність.

Сприймання - здатність бути уважним.

Реагування - ступінь активності.

Переконаність - готовність відстоювати власну точку зору, вміння вибирати цінності та ідеї.

Селективність - здатність виділяти головне.

Індивідуальність - вищий рівень сформованості особистості, що визначається індивідуальною лінією поведінки.

Практичне заняття проводиться традиційно у три етапи: підготовчий, основний та заключний. Кожний з цих етапів потребує певного методичного забезпечення. Викладач розробляє чіткий план практичного заняття, формулює питання теми у певній логічній послідовності, розподіляє їх за часом та визначає рівень засвоєння; визначає дисципліни з якими інтегрується тема заняття. На підготовчому етапі викладач має чітко сформулювати навчальні цілі і довести їх до свідомості студентів, що забезпечить високий рівень мотивації та пізнавального інтересу до теми. Ефективність контролю вихідного рівня теоретичної і практичної підготовки студентів залежить від різноманітності методів. На даному етапі заняття доцільно використовувати такі матеріали контролю: питання, тести різного рівня складності з еталонами відповідей, задачі різного рівня складності, графічні диктанти. Вибір засобів педагогічної діагностики базується на відповідних дидактичних принципах вимірювання результатів навчання. Лише підготовлений відповідним чином комплекс завдань дає змогу, з використанням певних діагностичних методів, правильно оцінити рівень знань і вмінь суб'єктів навчання. Ось чому в педагогіці останнім часом виникла тенденція до використання кількісних методів педагогічного контролю. Серед засобів об'єктивного контролю найбільш науково обґрунтованим $є$ метод тестування. Складання тестових завдань потребує особливої підготовки викладача, спеціальних знань у галузі стандартизованих методів контролю якості освіти. Створюючи тести, викладач прагне, щоб вони були об'єктивними, валідними, надійними, стандартизованими.

Основний етап практичного заняття передбачає формування професійних вмінь та навичок, що $€$ необхідною умовою для успішної роботи у сфері професійної діяльності (психомоторна сфера, пов'язана з рухами, маніпуляціями з матеріалом або об'єктом, а також з координацією). Плануючи основний етап практичного заняття, необхідно врахувати п'ять класів психомоторної сфери відповідно до рівня розвитку психомоторних здібностей студента.

Перший клас: повторення дії внаслідок спостереження та наслідування - імітація.

Другий клас: дія за інструкцією, що зафіксована в усвідомленому вмінні, -маніпуляція.

Третій клас: повноцінне, впевнене (без інструкцій) виконання дії, що контролюється свідомістю.

Четвертий клас: вміння виконувати узгоджено сукупність дій з усвідомленим контролем.

П'ятий клас: вміння виконувати сукупність дій автоматично з повним засвоєнням знань. Для реалізації цього етапу викладач розробляє різноманітні інструктивні матеріали: професійні алгоритми, сценарії для ділових, рольових ігор, навчальні задачі типові та 
нестандартні, максимально наближені до реальної практики.

Активним методом навчання $є$ ділова гра, яку доцільно застосувати на етапі формування вмінь та навичок. Ділова гра надає можливість вирішити наступні педагогічні задачі:

- формування у студентів цілісного уявлення про професійну діяльність та ії динаміку;

- розвиток теоретичного та практичного мислення у професійній сфері;

- набуття проблемно-професійного та соціального досвіду;

- формування взаємовідносин з іншими людьми;

- розвиток творчих та професійних здібностей;

- набуття навичок прийняття індивідуальних та колективних рішень;

- формування пізнавальної мотивації, забезпечення професійної мотивації.

Для проведення ділової гри викладач формулює не тільки навчальні цілі, а й цілі розвитку особистості; обмірковує емоційний та мотиваційний фон гри.

Наступний етап підготовки документації до ділової гри - розробка плану, загального опису гри та критеріїв оцінки результатів ігрової діяльності студентів. У критеріях оцінювання враховуються:

- відповідність прийнятих в ході гри рішень задачам та умовам ігрової діяльності;

- швидкість прийняття рішень;

- точність виконання професійних алгоритмів;

- аргументованість прийнятих рішень у процесі підсумкової дискусії.

Таким чином, сценарій ділової гри має бути підготовлений у вигляді методичних документів.

На етапі практичного тренінгу застосовуємо стандарти діяльності (протоколи медичної сестри (фельдшера, акушерки) з догляду за пацієнтом і

\section{ЛITEPATУРА}

1. Фіцула М. М. Підготовка вчителя до уроку / М. М. Фіцула // Педагогіка. - К., 2009. - С. 198-201.

2. Шегедин М. Б. Розвиток сестринської справи в Росії / М. Б. Шегедин // Медсестринство у світі. - Львів, 1999. C. $35-40$. виконання основних медичних процедур та маніпуляцій).

На заключному етапі практичного заняття викладач застосовує навчальні нетипові задачі, тести, що потребує відповідної підготовки.

Пізнавальна задача містить певні протиріччя в своїй умові і завершується питанням, яке це протиріччя активізує. Рішенням задачі - $є$ вирішення заданого в її умові протиріччя (наявність елементів ускладнення, нетиповості, нестандартності).

Головною методичною вимогою до навчальних задач є диференційний підхід до їх складання та використання з огляду на цілі професійної підготовки. Особливе місце посідають задачі III рівня складності. Створюючи задачі, необхідно максимально наблизити їх до реальних сучасних задач медичної практики, врахувати проблемний та міждисциплінарний аспект. Рішення задач передбачає не тільки формування і закріплення стереотипу поведінки майбутнього медичного фахівця, а й розвиток професійного мовлення. Ми навчаємо студентів як звернутись до пацієнта, як побудувати розмову залежно від захворювання в пацієнта, тяжкості його перебігу, його емоційного стану, віку, статі та ін. Ці задачі вимагають від викладача розробки детальних різноманітних діалогів, сценаріїв.

Висновки. Активні методи навчання активізують навчальний процес, спонукають студентів до активної участі в ньому. Такий підхід виключає можливість отримання студентом негативної оцінки на занятті і стимулює пізнавальний інтерес до навчання.

Різноманітність методів, методик та їх методичне забезпечення дозволяє викладачу бути мобільним на занятті, залучати до активної праці усіх студентів незалежно від їх підготовленості. Для викладача розробка методичного забезпечення різних активних та інтерактивних методів навчання $є$ потужним джерелом для розкриття свого творчого потенціалу.

3. Милерян В. Є. Методичні основи підготовки та проведення навчальних занять у медичних вузах / В. Є. Милерян. - К., 2001. - С. 4-9.

4. Волкова Н. П. Педагогіка / Н. П. Волкова. - К., 2001. С. 332-333.

5. Булах І. Є. Створюємо якісний тест : навчальний посібник для викладачів, учителів і методистів / І. Є. Булах, М. Р. Мруха. - К. : Майстер клас, 2006. - 160 с. 